Article

\title{
The Military's Links with Local Communities in the Context of Sustainable Development
}

\author{
Stanisław Sirko ${ }^{1}$, Jarosław Kozuba ${ }^{2, *}$ (D) and Marzena Piotrowska-Trybull ${ }^{1}$ \\ 1 Faculty of Management and Command, War Studies University, 00-910 Warsaw, Poland \\ 2 Faculty of Transport, Katowice, Silesian University of Technology, 44-100 Gliwice, Poland \\ * Correspondence: jaroslaw.kozuba@polsl.pl
}

Received: 7 July 2019; Accepted: 13 August 2019; Published: 16 August 2019

check for updates

\begin{abstract}
This article focuses on the analysis of the military links with local communities in the context of sustainable development, in particular the social and economic aspects of development. The aim of the article is to identify and characterize the links between military units and entities in the local environment on the example of selected municipalities in Poland and to assess these links in the opinion of residents, local authorities, and soldiers. Between military units and local communities, there are relations of different nature and intensity, conditioned by internal and external factors. The military stationed on the territory of individual municipalities makes a direct and indirect contribution to building the social and economic potential of these places, as well as providing public goods in the form of the national defence. The links between the military and local communities are discussed in the source literature with reference to examples from different countries. While the scale and scope of these links vary, these impacts follow similar patterns.
\end{abstract}

Keywords: local community; army; local government; relations; local development; sustainable development

\section{Introduction}

Development is the result of human activity, the effects of which shape living conditions. Contemporary thinking about development is largely determined by actions to maintain balance in the social, economic, and environmental spheres. Meeting this condition means that such development is defined as sustainable development, and its superior objective is to live in harmony with nature, which means elimination of such types of behavior that lead to "robbery" of resources by today's society, at the expense of conditions in which future generations will live [1] (p. 100). In the concept of sustainable development, microeconomic effectiveness, ecological rationality, and social legitimacy are essential [2] (p. 88), [3]. At the same time, the criterion of microeconomic effectiveness in the activity of entities is extended to include issues of rationality and ethics, constituting determinants of the assessment of the level of social and economic development.

Intensive social and economic development entailing specific benefits for human beings also causes a number of unfavorable consequences. Increased use of natural resources and energy contributes to the increase of environmental pollution, leading to the intensification of diseases of the respiratory system, cardiovascular system, and nervous system. This, in turn, determines the need to counteract these phenomena, and as a result, social and economic costs are increasing. Despite the passage of years and hopes placed in the development of technology, which has taken place since the first industrial revolution, humanity still struggles with hunger, poverty, social inequalities, diseases [4] (pp. 24-25), environmental pollution, and low quality of public services [5].

From the perspective of local communities, the problems of diversification of living standards and climate change caused by intensive human activity and related pollution of the natural environment 
deserve attention. As stressed by E.J. Blakely, E.G. Leigh diversity in living standards is an effect of [6] (pp. 4-23):

- Globalization, which weakens the control (both local and national) of global networks;

- $\quad$ increase in the wage (income) gap;

- $\quad$ employers' savings at the expense of employees;

- $\quad$ spatial resource inequalities between rural and urban areas and within cities.

Insufficient diversification of economic structure, insufficient level of capital and knowledge resources, lack or low quality of technical infrastructure, low level of entrepreneurship, lack of coherent vision of territory development, and lack of ability to direct and integrate social energy, in particular, the local leader of changes are the factors that limit local development. The development in this context is understood as a "process of diversification and enrichment of economic and social activities in a given territory, consisting in mobilisation and coordination of own resources and energy" [7] (p. 58). This process includes quantitative changes (size of fixed assets, employment, and investments) and qualitative changes that determine the level of services provided and their availability to the local community.

\section{Materials and Methods}

The article presents the results of research carried out by means of a diagnostic survey using a poll and interview techniques. It also discusses the results of analyses carried out on the basis of data from the following institutions:

- Communications from the Public Opinion Research Center-in the field of perception of the military by society as a public institution;

- the Central Statistical Office-socioeconomic data;

- Regional Infrastructure Management Offices-in the field of the size of taxes paid and types of works commissioned by the army through tenders to enterprises in the vicinity of units.

Excel and Statistica were used to analyze the collected material.

The surveys among the inhabitants of the municipalities where the military unit is stationed were conducted in 2010 and 2017. After the authors of the article had prepared research tools, the survey among the inhabitants of municipalities and representatives of local governments was conducted by MillwardBrown SMG/KRC (2010) and ASM (2017). In 2010, the surveys were carried out in seventeen randomly selected municipalities (9 urban municipalities, 1 urban-rural municipality, and 7 rural municipalities) located on the territory of Poland. They were carried out in three stages: 1 -a research tool (questionnaire) was prepared, 2-basic statistical material was collected, and 3-data was explored. The survey was conducted using the CATI (Computer Assisted Telephone Interview) method.

At least fifty randomly selected persons participated in the survey in each of the municipalities (further on, the results from 2010 were presented, taking into account only the responses of the inhabitants of the municipalities-503 persons). In this period, the survey was also conducted among 33 representatives of local governments, from which, in the years 1990-2009, military units were withdrawn, and among 26 representatives of local governments, where, in 2010, military units were stationed. The questionnaires were conducted with nine municipality heads and mayors [8]. In 2017, residents of five urban municipalities (Braniewo, Brzeg, Chełmno, Hrubieszów, and Słupsk) in which research was conducted in 2010 were asked again for an opinion on the impact of a military unit on the social and economic situation in their municipalities. At that time, 600 people randomly drawn from individual municipalities took part in the survey. In 2017, when drawing on the participants, the proportions of persons living in each of the municipalities were taken into account [8].

The questions included in the questionnaires in 2010 and 2017 were essentially categorized questions. The respondents could also express their opinions in open questions. During the analysis of 
the collected statistical material, measures of descriptive statistics were used, and were adequate to the questionnaires and measurement scales used in the questionnaire. The $\chi^{2}$ test was used to verify statistical hypotheses. The results were statistically significant at the level of 0.05

The article also presents the selected results of the analysis of data obtained from the Regional Infrastructure Management Boards (RZI), on the 2007-2014 revenue brought to the budget of 411 municipalities by the stationed military units from tax on real estate, agricultural, forestry, and means of transport [9]. From the RZIs' websites, information was also obtained regarding the awarded tenders for repairs, on the premises of military units or for certain product deliveries. The analysis covered 623 reports containing information on the awarded tenders in the District Management Boards of Infrastructure of Gdynia, Lublin, Poznań, in the period from January to December 2011 and 710 reports published on the websites of RZIs in Bydgoszcz, Gdynia, Kraków, Lublin, Olsztyn, Poznań, Szczecin, Wrocław, Warsaw, and Zielona Góra, informing about the awarded tenders in the first half of 2012. In total, 1333 reports were analyzed. Statistica [8] was used to analyze the collected data.

\section{Relations between the Army and Local Government}

Local government and military units are included in the public sector, which provides public goods to society. As a rule, the availability of goods for the society does not decrease as a result of their use by other persons [10] (p. 69), the so-called principle of universal accessibility.

The production and consumption of public goods is not regulated solely by the market mechanism, which is dictated by the diversity of purchasing power of individual persons, who, in the case of insufficient income, could be deprived of access to these goods, or according to their preferences, consciously give up their consumption (e.g., education, culture, health, and safety). Thus, the consumption of these goods is an expression of social inclusion, consisting in the incorporation of different individuals in this process in order to prevent their economic exclusion [11] (p. 48) and is in the interest of the entire society, supporting the achievement of social and economic objectives assumed by the state.

The production of public goods takes place in both the public and private sectors, from which these goods are then bought and consumed by the general public. In practice, there are three ways of distributing these goods [11] (pp. 55-56):

- $\quad$ Everybody gets an equal share-the supply of goods corresponds to the existing demand (basic education, communication routes, and national defence);

- queue-consumption of goods is conditioned by the order in which the desire to satisfy a specific need is declared (services: Health and administrative). The length of waiting in the queue is conditioned by the "scarcity of labour and capital resources";

- $\quad$ user charges-consumption is possible if the user pays a fee which regulates the consumption of resources in a given period of time, in a situation when funds are needed for their restoration (services: water supply, sewage, and public transport).

The territorial self-government performs a number of public tasks aimed at ensuring the living conditions and development of the inhabitants, as well as the development of enterprises. The implementation of the tasks is possible based on effective use of endogenous resources, attracting exogenous resources and cooperation with entities in the environment. One of such entities are military units, with which the local government cooperates in the area of national security. Military units as a component of the Polish Armed Forces are responsible for providing the society with a public good, which is national defence. This is indicated by Article 26 of the Constitution of the Republic of Poland. "The Armed Forces of the Republic of Poland shall safeguard the independence and territorial integrity of the State, and shall ensure the security and inviolability of its borders" [12]. Units are deployed in garrisons inside the country, whose seat and scope of operation, taking into account the existing network of administrative and territorial division of the country, is determined by the Minister of National Defence. 
The task of ensuring state security by the military determines the creation of links between the military, society, and state institutions in the social, economic, and environmental spheres, which are of interest to representatives of philosophy, economics, sociology, political science, and other sciences [13] (pp. 33-46).

On the macroeconomic level, the military participates in the division and consumption of goods created in other branches of the economy, and at the same time, produces the public good, which is national defence. In this case, the issue under discussion is the allocation of public resources between alternative uses, including defence [14] (pp. 399-411), [15] (pp. 86), [16] (p. 43).

On the microeconomic level, the military, as an element of the local economy, supports to some extent the development potential of a specific area, although its activities are primarily aimed at ensuring external security for the general public [17] (p. 368), [18] (pp. 127-128).

\section{Development of Local Communities}

The basic features of local development are its "territoriality", interactions between people in a given territory, common social interest, local sentiment, and institutions established to satisfy the needs of hybrids [19] (p. 120). Territoriality means benefiting from the possession of particular resources and skills, embedded in a specific geographical, economic, and social space. Referring to the concept of local development, it is worth emphasizing the local word, which can be understood as "historical, economic, social, cultural and symbolic space with its own dynamics" [7] (p. 58), the space that belongs to inhabitants and is shaped by them. Thus, localism is a certain developmental proposal in communities that are determined to shape changes in the space they live in and in which they administer. The institutional expression of local communities in Poland are municipalities. The municipalities are differentiated in terms of: Structure of resources, degree of concentration of these resources, ability of effective action and cooperation of entities located in a given territory, development dynamics, functions performed for the benefit of the environment, and strength and nature of links with other territorial units (municipalities, counties, and voivodeships) [20]. Differences resulting from management not only indicate the fact that resources exist, but also that the possibility to use them in order to bring benefits to the local community is important for dynamic local development. As a consequence, in theory there is a distinction between resources (potential factors of development) and assets (active factors used by local society in different socio-economic processes) and their universal and specific character [7] (p. 113). Within each territory, there are resources that represent the potential of the territorial unit (unused: Labor resources, raw materials, information, and infrastructure) and assets that are "active factors" — conductive to development (highly qualified work, knowledge, and specialist equipment [7] (pp. 110-115). The universal character determines the universality of individual factors, and thus their occurrence in most, if not all, units of a particular type. The specific nature of resources and assets, in turn, refers to their scarcity, which determines the possibility of building a competitive advantage of a given territorial unit. This is due to the fact that it is sometimes very difficult to transfer specific factors in the same configuration and to be able to imitate them elsewhere.

The determinants of local development are the high quality of life of the inhabitants, the effectiveness of enterprises in a given territory, as well as the state of the natural environment. From the point of view of the inhabitants, it is advantageous to diversify the labor market, in particular in terms of industries and the structure of located enterprises, which report the demand for workers with different qualifications. The remuneration of employees for work determines their consumption possibilities and influences the development of the service sector. Whereas, from the point of view of conditions necessary for the development and effectiveness of enterprises, such elements as qualified employees, entrepreneurial, and innovative environment-open to cooperation, and at the same time, competitive to external entities, price level and availability of land for investments, and availability and quality of technical infrastructure are important. Efficiently operating enterprises through the tax system supply local budgets, thus influencing the level and scope of public services, create jobs, so that households have financial resources to purchase goods and services. An important role among the 
factors determining local development is also played by state institutions that initiate activities and are responsible for their implementation, including the army that is financed by the central budget.

Between military units stationed on the territory of particular municipalities, and entities in the local environment, bilateral relations are formed, aimed at cooperation. Recently, there has been a noticeable increase in the interest of the inhabitants of particular municipalities in cooperation with the military. According to data obtained from the General Command of the Armed Forces Types (GCAFT), in 2014 the number of cooperation agreements was 720 (including 319 agreements with non-government organizations-NGOs, 401 with other social partners). In the following year, 2015, the total number of agreements increased to 883 (by $22.6 \%$ compared to the previous year). More than one third of them $(35.0 \%)$ were signed with NGOs, while the remaining two thirds with other social partners. In 2014, the military units subordinate to GCAFT implemented a total of 3187 projects with the social partners, of which about $34 \%$ were projects implemented outside the plan. In the following year, the total number of undertakings carried out in cooperation with the social partners amounted to 5107 (an increase by nearly $38 \%$ as compared to 2014), of which $26 \%$ were implemented outside the plan. In 2014, out of 2847 projects included in the cooperation plan, 2107 were completed during the year, which constituted $66 \%$ of the assumed projects. Most of the projects were carried out with schools-1060 (in total included in and outside the plan) and associations and unions of associations (including sports unions and associations of physical culture) and foundations-1029 (in and outside the plan) [21] (pp. 17-18), [22] (p. 22).

\section{Results of the Research}

Military units operating in the public space, to a greater or lesser extent engage in the issues of local communities, cooperating with them in crisis situations and during the organization of various projects [8]. They are located according to the needs resulting from operational conditions. Sometimes these areas are less accessible for people; sometimes they are attractive for tourists. Their presence positively influences the sense of security of the residents, they are the employer (sometimes the largest) for the local population (important for the municipalities with the population under 100,000 inhabitants), the employer in the case of overhauls, repairs or supplies, and finally the payer of taxes: Agricultural, real estate, and forestry. This means that they have a greater or lesser impact on the financial situation of the municipality in which they are stationed (Figure 1).

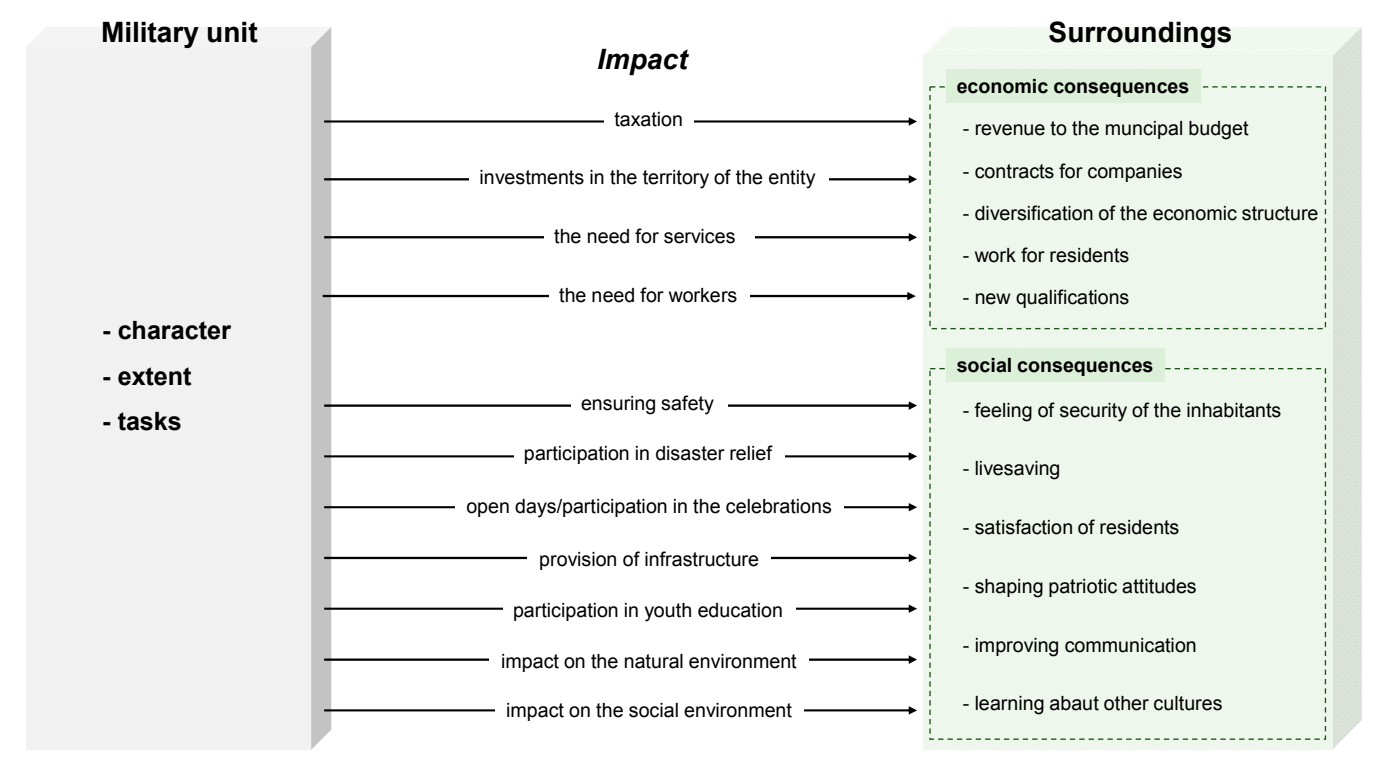

Figure 1. Impact of a military unit on the situation in its environment. Source: Own preparation. 
The analysis of foreign and domestic studies by authors shows that the influence of the armed forces on development on a local and regional scale is presented mainly in the context of the effects of military withdrawal from a municipality or other territorial unit. Liquidation of military units has a differentiated impact on local development, depending on the type of territorial unit in which the army was stationed-city or village [23]. In cities, a diverse economic structure and existing population potential support the process of shifting resources left over to other public or private purposes. In rural areas, sometimes remote from large urban centers with smaller population and economic potential, such opportunities are relatively smaller. In the publications, attention is drawn to the following: The most important of these are increased unemployment and employment $[23,24]$, production limitations, lower incomes and demand [25], and migration [26-30]. As a result of the decrease in the number of inhabitants (soldiers leaving with their families), the number of children in kindergartens and schools is decreasing $[31,32]$ together with the decrease in number of people using other services in the public sector exposed at quality decline stemming from diminishing income to the budget. The intensification of migration processes contributes to the increase in the supply of housing resources, which-especially in rural areas-are difficult to manage.

The impact of the unit on the situation in the municipality is also confirmed by the results of research conducted by the authors of the article since the beginning of this decade. From the perspective of municipality inhabitants, a stable situation in their place of residence, work, education and country is important, because in such a situation both they and local authorities focus more on those elements that are closer to them. The Armed Forces of the Republic of Poland play an important role in satisfying the need for living in conditions of peace and stability. In the light of information contained in the Public Opinion Research Center's announcements since the beginning of the 1990s, they enjoy relatively high trust of the Poles [33]. Good reception of this institution by the inhabitants of municipalities and representatives of local governments throughout the country is also confirmed by the results of own research [8,34]. In 2010, in the opinion of 53.5\%, and in 2017 according to $57.0 \%$, of the surveyed municipality residents, the presence of a military unit in a municipality contributes to making people feel safer. Both in 2010 and 2017, in municipalities located in the Eastern and Northeastern part of the country, a larger percentage of respondents noticed a beneficial influence of military presence on the sense of security of the inhabitants.

According to the majority of the respondents (67.6\% in 2010 and 61.0\% in 2017), the relations between the military unit and the local environment were good and very good. The highest percentage of the responses indicating positive military ties with the environment was found in the group of the youngest respondents. It can be probably explained by the cooperation of military units with schools, and the involvement of soldiers in shaping patriotic attitudes among youth. Cooperation between the military unit and schools in the municipality is carried out in the form of discussions, lectures, shows held in schools or units during open days, as well as in the form of rallies, sports competitions, and youth camps. Sometimes soldiers participate in organizing free time for students or work for the school.

According to a large group of respondents (41.7\% in 2010 and $49.6 \%$ in 2017), the presence of a military unit affects the quality of life in a municipality. Military units influence local labor markets to a larger or lesser extent. On the other hand, they may be an employer for citizens coming from a municipality and from outside, on the other hand, as a result of their liquidation, more unemployed people may appear on the labor market or reduce employment, which in turn has consequences for the size of the local budget. Respondents' opinions on the role of a military unit in local labor markets are divided depending on the socio-economic situation of municipalities, labor market diversification, number of economic entities located there, as well as distance to jobs in other municipalities.

In order to find out how the dismissal of specific number of people $(100,250,600)$ may affect the situation on the labor market in municipalities, appropriate calculations were carried out. The analysis of the results showed that regardless of whether 100, 250, or 600 workers were made redundant, the effects of this measure were the most troublesome for rural municipalities. For some, the dismissal 
of 100 persons already contributed to an increase in the number of unemployed people by about 40 percentage points, for others it caused the situation to deteriorate by only a few percentage points [8].

The military units are the places employing soldiers and military workers. Soldiers often come with their families, and when they leave the service, some of them, such as pensioners, remain in the municipality permanently. This group, with a fixed income, offers the possibility of selling products or providing services by local businesses. The stationing of a military unit in the territory of the municipality is also important for other reasons. Belonging to the public finance sector, they settle their accounts with the local budget through the Regional Infrastructure Management Offices, which transfer to the municipal budget: Real estate tax, agricultural tax, and forest tax. The share of these taxes in the income of the municipality is different for each of them (Figure 2).

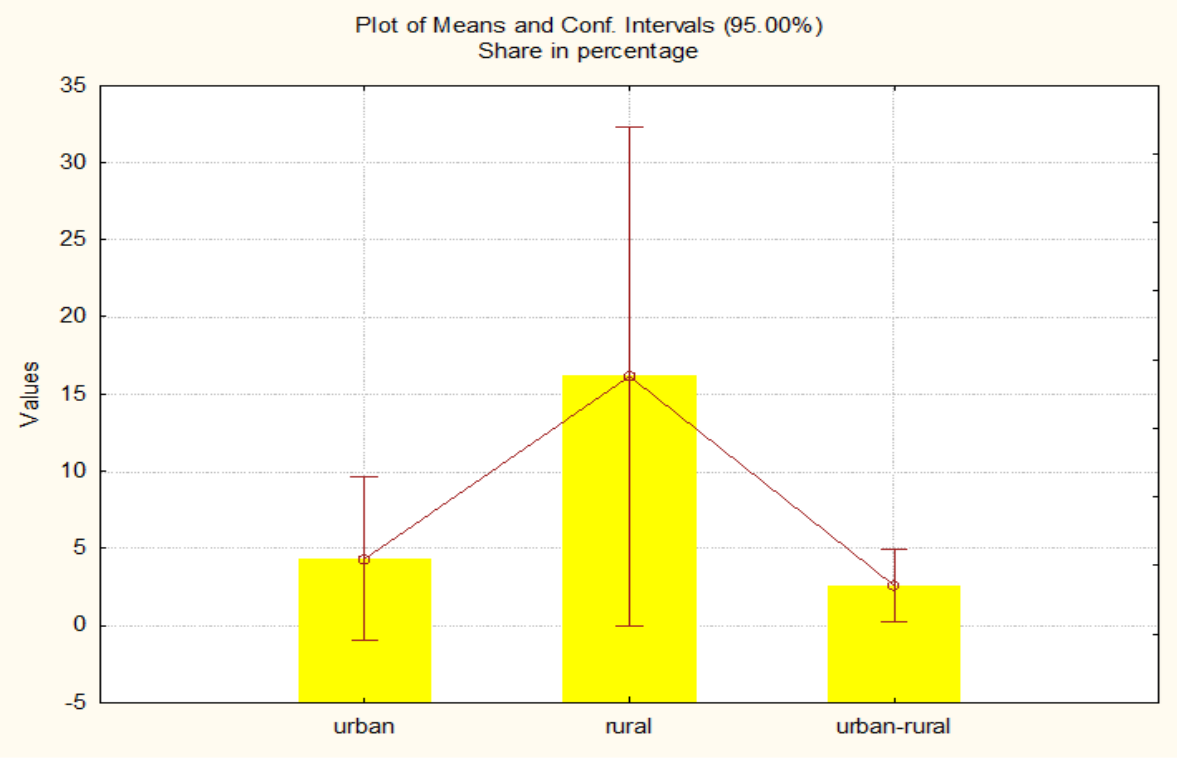

Figure 2. Average values of the share of tax revenues paid by military units in the revenues of municipalities/data in \%/Source: Own preparation.

As results from the analysis of data obtained from the Regional Infrastructure Management Offices (RIMO), the receipts to the budget of urban-rural, rural, and urban municipalities from the property tax paid by military units are different. Their average value for the years 2007-2014 was as follows: Urban-rural municipalities (EUR 376,056), rural municipalities (EUR 606,331), and urban municipalities (EUR 1,130,894).

In the years 2007-2013, the revenues to the budgets of individual municipalities from property, agricultural and forestry taxes were the highest in the municipalities of the West Pomeranian, Greater Poland and Lower Silesian voivodeships (the biggest regional unit of territorial division in Poland with regional administration). In others (e.g., Warmian-Masurian, Pomeranian, Łódź, Kuyavian-Pomeranian), they were two times smaller than in Greater Poland and three times smaller than in West Pomeranian. Whereas, the highest agricultural tax revenues were recorded in the municipalities of the Lower Silesian, Warmian-Masurian, and Subcarpathian voivodeships. An important role was also played by the revenues to the budgets of the municipalities from the forestry tax. They were the largest in Lubusz, Subcarpathian, and West Pomeranian voivodeships. In the period from 2007 to 2013, military units were transferring more and more income to municipalities in particular voivodeships every year.

In the period presented (2007-2014), the budget of 127 municipalities was supplied by payments for agricultural tax. The highest receipts were recorded in municipalities (in the order of decreasing total payments): Lidzbark Warmiński (urban), Ustrzyki Dolne (urban), Wisznia Mała (rural), Długołęka 
(rural), Miękinia (rural), Braniewo (rural), and Starbmierz (rural). The smallest sums of money were transferred to the budgets of municipalities: Wierzchowo (rural), Słupsk (urban), and Zaklików (rural).

Forest complexes are natural masking elements, often used by military units. This means that military units, stationed in forest areas, pay forestry tax. Most of the money was transferred to the municipalities: Osiecznica (rural), Sulęcin (urban), Bojanów (rural), Żagań (rural), Łuków (rural), and Grębów (rural). Such payments were transferred to the cash registers of seventy-seven municipalities. The smallest amounts were transferred to: Duszniki Zdrój (urban), Głogów (rural), and Jastków (rural).

In the case of rural municipalities, the amounts of taxes paid by military units have a significant impact on their income (average values of the share of tax revenues paid by military units in the income of rural municipalities: $16.2 \%$, urban $4.3 \%$, and urban-rural $2.6 \%$ ).

It is clear from the data quoted above that in case of rural municipalities the sums obtained have a significant impact on municipalities' income. In the situation of such municipalities as Suchy Las, Buczek, and Wielka Nieszawka, where this share is in the order of several dozen percent, the lack of tax payments will be clearly noticeable. In case of other rural municipalities: Pawonków, Inowłódz, and Jedlnia Letnisko, where the share of income from taxes paid by the army does not exceed one percent, the lack of this source of financial support for the municipality will be felt to a minimum extent.

When analyzing the ration of the amount of tax payments paid by military units per one inhabitant of a municipality, for individual municipalities, these values were different, depending on both the amount taxes and the number of municipalities' inhabitants. The municipalities with the lowest income per capita were: Jasło, Nowy Targ, Nowy Tomyśl, and Busko Zdrój.

Military units may influence companies in municipalities, because, as a result of using facilities, there is a periodical need to renovate them. New facilities are also being built, which means that external entities, as a result of organized tenders, are involved in the implementation of various investments. In this situation, as well as in order to select suppliers of specific resources, tenders are carried out. The way in which the armed forces are supplied, the specific nature of the military units and the type of contracts make the public procurement system different. In addition, the need for quick service delivery and meeting additional requirements (e.g., in the area of security) they do not facilitate the implementation of tenders. Regional Infrastructure Management Offices (RZI) participate in the settlement of tenders for construction, expansion, modernization, and repairs.

RZIs are subordinated to the Head of the Armed Forces Support Inspectorate. They were appointed to perform tasks related to military accommodation and management of property administered by the Minister of National Defence. The Armed Forces participate in the settlement of tenders for activities contributing to the efficient functioning of military units (construction works, repair and maintenance works, provision of specific services and supply of equipment or materials). On the basis of information provided on their websites, analyses have been carried out in order to assess to what extent tenders carried out by the Regional Infrastructure Management Offices and concerning various investments in armed forces units may affect companies in the vicinity of the military unit's stationing place.

As a result of the analyses, a certain image of the impact of investments carried out in units on their immediate surroundings was obtained. While the general dependencies are similar, in each Regional Infrastructure Management Office, and consequently in each region, there is some variation both in the scope of implementation of tenders, subjects of these tenders, areas to which financial resources are transferred, both from the perspective of industries, and the distance of tender participants from the place of execution of orders. The following companies participated in the tenders: Companies which conducted activities related to trade and services (46.4\% of all companies), providing repair and construction services (42.0\%), providing deliveries (9.4\%), and multi-branch companies $(2.2 \%)$. It should be remembered, however, that the presented analysis results refer to a relatively short period of time and different localizations—urban and rural municipalities. 


\section{Conclusions}

The intensity of the military links with local communities is conditioned by many internal and external factors. Social, economic, and environmental links analyzed in the context of sustainable development indicate that the military, as a state institution, in addition to providing the public good, in the form of national defence for the general public, contributes to building the potential of the territory where it is located. This contribution can be identified in relation to the military's impact on local labor markets (increase of employment), the income situation of the inhabitants (stabilisation of revenue level), the size of the local budget (in urban municipalities-revenue from property tax, in rural municipalities-revenue from agricultural tax), the size and quality of public services (annual sustainable revenues from military units), the intensification of trade and the financial health of the companies that provide products and services to individuals.

The respondents stressed the role of the military unit in diversifying the local labor market, increasing the inflow of new residents to the municipalities due to the presence of the unit, exerting impact on shaping patriotic attitudes among youth (cooperation with NGOs and other social partners), exercising influence on the real estate market (purchasing and renting houses and flats by soldiers), and bringing recognition to the municipalities. The military enjoys high social trust and was perceived by most of the respondents as an entity conducive to security, despite the fact that, at the local level, this influence is indirect. The importance of the army in ensuring security was noticed mainly by the inhabitants of municipalities located near the state border (Braniewo and Hrubieszów).

In the social and economic dimension, we can speak about the direct and indirect influence of the army on the living conditions of the inhabitants and the conditions of conducting business activity in the municipality, as components of sustainable development. At the same time, the research conducted so far allows us to conclude that, along with the increase in the population potential and the stronger and more diversified economic structure of a municipality, it is more difficult to assess the impact of the military unit on the social and economic situation of a municipality in the context of its development potential.

Author Contributions: Conceptualization-S.S., M.P.-T., J.K.; Methodology-S.S., M.P.-T., J.K.; Collection, analyses or interpretation of data-S.S., M.P.-T., J.K.; Writing-Original Draft Preparation-S.S., M.P.-T., J.K.; Writing -Review \& Editing-S.S., M.P.-T., J.K.; Formulating Conclusions-S.S., M.P.-T., J.K.

Funding: This scientific work was financed by the resources for education as a research project of Ministry of Science and Higher Education No O N115 311238 and by the resources for science of Faculty of Management and Command, War Studies University and Faculty of Transport, Silesian University of Technology.

Conflicts of Interest: The authors declare no conflict of interest.

\section{References}

1. Ponikowski, H. O trzech zasadach zrównoważonego rozwoju terytorialnego. In Rozwój regionalny a Rozwój Zrównoważony; Bocian, A.F., Ed.; Wydawnictwo Uniwersytetu w Białymstoku: Białystok, Poland, 2008. (In Polish)

2. Korenik, S. Region Ekonomiczny w Nowych Realiach Społeczno-Gospodarczych; CeDeWu: Warsaw, Poland, 2011. (In Polish)

3. Helliwell, J.; Layard, R.; Sachs, J. World Happiness Report 2019. Available online: https://s3.amazonaws. com/happiness-report/2019/WHR19.pdf (accessed on 16 July 2019).

4. Jałowiecki, B. Lokalne ruchy społeczne w perspektywie procesów globalnych. In Problemy Rozwoju Lokalnego; Dutkiewicz, P., Gorzelak, G., Eds.; Wydawnictwo UW: Warsaw, Poland, 1988. (In Polish)

5. United Nations. The Sustainable Development Goals Report 2018; United Nations: New York, NY, USA, 2018.

6. Blakely, E.J.; Leigh, E.G. Planning Local Economic Development, Theory and Practice, 4th ed.; SAGE Publications, Inc.: Thousand Oaks, CA, USA, 2010.

7. Jewtuchowicz, A. Terytorium i Wspótczesne Dylematy jego Rozwoju; Wydawnictwo Uniwersytetu Łódzkiego: Łódź, Poland, 2013. (In Polish) 
8. Sirko, S.; Piotrowska-Trybull, M. (Eds.) Uwarunkowania Lokalne i Regionalne Funkcjonowania Jednostek Wojskowych na Terytorium kraju; Wydawnictwo AON: Warsaw, Poland, 2013. (In Polish)

9. Sirko, S.; Piotrowska-Trybull, M. Zakres i Siła Oddziaływania Czynników Wptywających na Wspótpracę Jednostek Wojskowych z Lokalnym Środowiskiem; AON: Warsaw, Poland, 2015. (In Polish)

10. Black, J. Słownik Ekonomii; Wydawnictwo Naukowe PWN: Warsaw, Poland, 2008. (In Polish)

11. Brol, M. (Ed.) Zarys Ekonomii Sektora Publicznego; Wydawnictwo Uniwersytet Ekonomicznego we Wrocławiu: Wrocław, Poland, 2010. (In Polish)

12. The Constitution of the Republic of Poland. Available online: http://www.sejm.gov.pl/prawo/konst/angielski/ kon1.htm (accessed on 9 August 2019).

13. Piotrowska-Trybull, M. Jednostki Wojskowe w Rozwoju Lokalnym w Polsce po 1989; ZN AON Wydawnictwo AON: Warsaw, Poland, 2013. (In Polish)

14. Smith, A. Badania nad Natura i Przyczynami Bogactwa Narodów; PWN: Warsaw, Poland, 1954. (In Polish)

15. Galbraith, J.K. Godne Społeczeństwo. Program Troski o Ludzkość; Dom Wydawniczy Bellona: Warsaw, Poland, 1999. (In Polish)

16. Smith, R. Przydatność Siły Militarnej: Sztuka Wojenna we Współczesnym Świecie; PISM: Warsaw, Poland, 2010. (In Polish)

17. Hicks, L.; Raney, C. The social impact of military growth in St. Mary's County, Maryland, 1940-1995. Armed Forces Soc. 2003, 29, 353-371. [CrossRef]

18. Polski, J. Ekonomika rozwoju regionalnego. Teoria i praktyka. In Rozwój Regionalny. Podstawowe cele $i$ Wyzwania; Bocian, A.F., Ed.; Wydawnictwo Uniwersytetu w Białymstoku: Białystok, Poland, 2007. (In Polish)

19. Białyszewski, H.; Dobieszewski, A.; Janicki, J. Socjologia; ALMAMER: Warsaw, Poland, 2006. (In Polish)

20. Ignasiak-Szulc, A.; Piotrowska-Trybull, M. Przedsiębiorczość w Rozwoju Regionów; Wydawnictwo AON: Warsaw, Poland, 2009. (In Polish)

21. Informacja o wynikach wspótpracy Dowództwa Generalnego Rodzajów Sił Zbrojnych i podległych jednostek wojskowych z partnerami społecznymi w 2014 r.; DG RSZ: Warsaw, Poland, 23 March 2015. (In Polish)

22. Informacja o wynikach wspótpracy Dowództwa Generalnego Rodzajów Sił Zbrojnych i podległych jednostek wojskowych z partnerami społecznymi w 2015 r.; DG RSZ: Warsaw, Poland, 1 March 2016. (In Polish)

23. Stenberg, P.L.; Rowley, T.D. A Comparison of Military Base Closures in Metro and Nonmetro Counties, 1961-1990; Staff Report No. Ages 9307. AgEcon Search: Washington, DC, USA, 1993. Available online: https: //ageconsearch.umn.edu/record/278693/ (accessed on 9 August 2019).

24. Stenberg, P.L. Rural Communities and Military Base Closures. Rural Dev. Perspect. 1998, 13, 10-18.

25. Paloyo, A.R.; Vance, C.; Vorell, M. The regional economic effects of military base realignments and closures in Germany. Def. Peace Econ. 2010, 21, 567-579. [CrossRef]

26. Andersson, L.; Lundberg, J.; Sjöström, M. Regional effects of military base closures: The case of Sweden. Def. Peace Econ. 2007, 18, 87-97. [CrossRef]

27. Iwanek, T. Problemy Zarzadzania Czynnikiem Ludzkim w Aspekcie Restrukturyzacji Sił Zbrojnych RP; WBBS: Warsaw, Poland, 2002. (In Polish)

28. Cieślarczyk, M. Społeczne Konsekwencje Restrukturyzacji Sił Zbrojnych w Odbiorze Lokalnych Środowisk Wojskowych; WBBS: Warsaw, Poland, 2000. (In Polish)

29. Sirko, S. Oficerowie i pracownicy wojska w świetle zmian Sił Zbrojnych RP. In Zarzadzanie Zmiana Wybrane Aspekty; Oliński, M., Ed.; UWM: Olsztyn, Poland, 2011. (In Polish)

30. Kozuba, J.; Kustra, M. Human Factor in Relation to Flight Safety; Zeszyty Naukowe WSOSP: Dęblin, Poland, 2016. (In Polish)

31. Piotrowska-Trybull, M. Rozwój Miasta Daugavpils w Perspektywie Militarnej i Gospodarczej; Zeszyty Naukowe Akademii Obrony Narodowej: Warsaw, Poland, 2011. (In Polish)

32. Thanner, M.H.; Segal, M.W. When the Military Leaves and Place Change. Effects of the Closing of an Army Post on the Local Community. Armed Forces Soc. 2008, 34, 662-681. [CrossRef]

33. Feliksiak, M. Ocena Działalności Instytucji Publicznych; Komunikat z badań, Nr 121/2018; CBOS: Warsaw, Poland, 2018. (In Polish) 
34. Piotrowska-Trybull, M.; Sirko, S. Sense of security among the citizens of municipalities in light of the military units presence within their territories. Socialo Zinatnu Vestnesis 2018, 1, 57-75.

(C) 2019 by the authors. Licensee MDPI, Basel, Switzerland. This article is an open access article distributed under the terms and conditions of the Creative Commons Attribution (CC BY) license (http://creativecommons.org/licenses/by/4.0/). 